\title{
ANALISIS PENGARUH POLA ASUH TERHADAP KECELAKAAN LALU LINTAS PADA PELAJAR SMA MENGGUNAKAN REGRESI LOGISTIK
}

\author{
ANALYSIS OF THE INFLUENCE OF PARENTING STYLE ON \\ TRAFFIC ACCIDENT IN SENIOR HIGH STUDENTS USING LOGISTIC \\ REGRESSION
}

\author{
Febrianti Qisti Arrum Bayumi ${ }^{1}$, Lucia Yovita Hendrati ${ }^{2}$ \\ 1,2Departemen Epidemiologi \\ Fakultas Kesehatan Masyarakat Universitas Airlangga \\ Jl. Mulyorejo Kampus C Unair Surabaya, Jawa Timur 60115, Indonesia \\ Alamat korespondensi: Febrianti Qisti Arrum Bayumi \\ E-mail: febriqisti@gmail.com
}

\begin{abstract}
Injuries due to traffic accidents were ranked eighth as health problem that caused deaths in several countries. Many traffic accidents occur in Africa and Southeast Asia with mortality rate of 26.6 and 20.7 deaths per 100,000 populations in 2016. East Java Province was ranked second as the location of traffic accidents on Java. Surabaya was ranked fifth as a contributor to the large number of road traffic accidents in East Java. The purpose of this study is to identify the relationship between parents' authoritarian parenting and the experience of teenage traffic accidents while riding a motorcycle. This research is a cross sectional study and uses two stage random sampling method. From the sampling process, as many as 222 students were obtained as respondents. The instrument used in this study consists of personal data and the Parental Authority Questionnaire (PAQ) to identify parenting style. Data analysis was carried out by logistic regression test with $\alpha=5 \%$. The data collection process was carried out during April-October 2017 in public and private high school in Surabaya. Logistic regression test results showed that there is no significant impact between parenting style and traffic accidents experienced by respondents (authoritarian $p=0.966 ;$ OR $=0.967$, permissive $p=0.616 ;$ OR $=1.556$ ). The conclusion of this study is that traffic accidents are not directly affected by parenting style, but it has role in forming individual characteristics, such as decision making and driving attitudes.
\end{abstract}

Keywords: parenting style, motorcycle accident, teenagers

\begin{abstract}
ABSTRAK
Cedera akibat kecelakaan lalu lintas menduduki peringkat kedelapan sebagai permasalahan kesehatan yang menyebabkan kematian dibeberapa negara. Kecelakaan lalu lintas banyak terjadi di wilayah Afrika dan Asia Tenggara dengan angka kematian sebesar 26,6 dan 20,7 kematian per 100.000 populasi pada 2016. Provinsi Jawa Timur menduduki peringkat kedua sebagai lokasi terjadinya kecelakaan lalu lintas di Pulau Jawa. Kota Surabaya menduduki peringkat terbesar kelima sebagai penyumbang angka kecelakaan lalu lintas di Provinsi Jawa Timur. Tujuan dari penelitian ini yakni untuk mengidentifikasi hubungan antara pola asuh autoritarian orang tua dengan pengalaman kecelakaan lalu lintas remaja saat mengendarai sepeda motor. Penelitian ini merupakan penelitian observasional dan menggunakan pendekatan cross sectional. Besar sampel yakni sebanyak 222 siswa sebagai responden. Instrumen yang digunakan adalah kuesioner data diri dan Parental Authority Questionnaire (PAQ) guna mengidentifikasi pola asuh orang tua responden. Data yang didapat dianalisis dengan uji regresi logistik dengan $\alpha=$ 5\%. Pengambilan sampel di SMA negeri dan swasta di Surabaya. Hasil uji-regresi logistik menunjukkan tidak ada pengaruh yang signifikan antara pola asuh orang tua dengan kecelakaan lalu lintas yang pernah dialami responden (authoritarian nilai $\mathrm{p}=0,966 ; \mathrm{OR}=0,967$, permisif nilai $\mathrm{p}=0,616 ; \mathrm{OR}=1,556$ ). Kesimpulan, kecelakaan lalu
\end{abstract}


lintas tidak dipengaruhi secara langsung oleh pola asuh orang tua, namun pola pengasuhan tersebut berperan dalam pembentukan karakteristik individu, salah satunya dalam hal pengambilan keputusan dan sikap berkendara.

Kata kunci: pola asuh, kecelakaan sepeda motor, remaja

\section{PENDAHULUAN}

Kecelakaan lalu lintas merupakan satu dari sekian banyak permasalahan kesehatan terbesar di sejumlah negara yang dapat menimbulkan cedera, kerugian materi, hingga kematian. World Health Organization (WHO) mengungkap, angka kematian yang timbul sebagai akibat dari kecelakaan lalu lintas secara global mencapai 18,2 per 100.000 populasi. Angka tersebut bervariasi di berbagai negara, yakni berkisar antara 9,3 sampai 26,6 per 100.000 populasi (WHO, 2018). Kecelakaan lalu lintas menduduki peringkat kedelapan tertinggi dibandingkan dengan permasalahan kesehatan lain yang dapat menyebabkan kematian di beberapa negara. Peringkat ini diperkirakan akan terus meningkat menjadi ketiga pada tahun 2020 (Masoumi et al., 2016).

Korban jiwa yang disebabkan oleh kecelakaan lalu lintas tertinggi terjadi di Afrika dan Asia Tenggara. Angka kematian pada kedua wilayah tersebut pada tahun 2013 mencapai 26,1 serta 19,8 per 100.000 penduduk. Angka tersebut meningkat menjadi 26,6 dan 20,7 kematian per 100.000 populasi di tahun 2016. Sebagian besar kecelakaan lalu lintas melibatkan kaum rentan sebagai korban, yakni pejalan kaki, pengendara motor, maupun sepeda angin. Kematian terbanyak yang terjadi di Asia Tenggara dan Pasifik Barat melibatkan sepeda motor, yakni sebesar $43 \%$ (WHO, 2018).

Permasalahan tersebut juga terjadi di Indonesia sebagai bagian dari Asia Tenggara, yang mana kecelakaan lalu lintas menduduki peringkat 10 sebagai salah satu penyebab kematian terbesar (Kemenkes RI, 2012). Pusat Krisis Kesehatan Kemenkes RI menyebutkan bahwa kecelakaan transportasi menduduki peringkat ketiga terbesar dalam kategori kejadian bencana non alam di Indonesia tahun 2017 (Kemenkes RI, 2018).
Saputra (2017) menyebutkan bahwa, angka kecelakaan tertinggi terjadi di Pulau Jawa. Provinsi Jawa Barat menduduki peringkat tertinggi sebagai lokasi terjadinya kecelakaan terbanyak sejak 2007 sampai 2016, dengan total 22 kasus. Komite Nasional Keselamatan Transportasi (KNKT) mencatat, Jawa Timur berada pada peringkat kedua dengan total 13 kasus kecelakaan lalu lintas.

Kota Surabaya menduduki peringkat kelima dengan angka kecelakaan lalu lintas tertinggi di Provinsi Jawa Timur (BPS Provinsi Jawa Timur, 2015). Kasus kecelakaan lalu lintas pada 2015 di Kota Surabaya mencapai lebih dari 800 kasus, dengan jumlah korban jiwa 195 orang, cedera berat 114 orang, dan cedera ringan 884 orang (BPS Kota Surabaya, 2017). Kecelakaan lalu lintas dapat menimbulkan kerugian materi hingga miliaran rupiah. Tahun 2015 , kerugian yang diakibatkan oleh kecelakaan lalu lintas ditaksir mencapai Rp 674.000.000,-. Jumlah tersebut menurun dibandingkan dengan kerugian materi yang ditimbulkan pada tahun 2014, yakni lebih dari Rp. 850.000.000,- (BPS Kota Surabaya, 2017).

Badan Pusat Statistika (BPS) menyebutkan dalam laporan Kota Surabaya Dalam Angka, mayoritas korban kecelakaan berada pada kelompok usia 17-21 tahun yakni sejumlah 434 orang. Data BPS juga menyebutkan bahwa pelaku dan korban kecelakaan didominasi oleh karyawan swasta yang menduduki peringkat pertama dan pelajar yang menduduki peringkat kedua, dengan mayoritas latar belakang pendidikan Sekolah Menengah Atas (SMA) (BPS Kota Surabaya, 2017).

Data yang tercatat oleh BPS Kota Surabaya menunjukkan bahwa, jenis kendaraan yang paling banyak terlibat dalam kecelakaan yakni sepeda motor dengan jumlah kasus sebanyak 1187 buah. Jumlah ini lebih tinggi dibandingkan pada tahun 
2014, yakni 972 buah sepeda motor (BPS Kota Surabaya, 2017).

Teori Haddon Matrix menyebutkan bahwa kecelakaan lalu lintas terjadi karena adanya interaksi antara beberapa kategori faktor risiko, yakni host, agent, dan environment. Faktor host atau pejamu, dalam hal ini pengendara misalnya jenis kelamin, usia, kelelahan, penggunaan helm maupun alat keamanan lain, dan sikap berkendara (Masoumi et al., 2016). Indriastuti, Fauziah dan Priyanto (2011) menyebutkan, faktor host adalah faktor yang paling mendominasi $(83 \%)$ dalam terjadinya kecelakaan lalu lintas.

Data kecelakaan lalu lintas yang dirangkum dalam Road Safety Annual Report tahun 2018 mengungkapkan, penyebab kematian terbesar pada remaja dan dewasa usia 15-20 tahun adalah kecelakaan lalu lintas. Kelompok usia 18-20 tahun memiliki risiko kematian yang disebabkan oleh kecelakaan lalu lintas 1 hingga 2 kali lebih besar dibandingkan kelompok usia lain (International Transport Forum, 2018). Selain usia, perbedaan besar risiko juga terjadi pada pria dan wanita. Laki-laki usia 18-24 tahun lebih cenderung memiliki risiko kematian akibat kecelakaan lalu lintas 2-3 kali lebih tinggi dibandingkan wanita pada kelompok usia yang sama (International Transport Forum, 2018).

Pengendara yang melaju dengan kecepatan tinggi lebih berisiko untuk mengalami kecelakaan lalu lintas yang fatal. Sebesar 20-30\% kecelakaan fatal yang terdata oleh International Transport Forum diakibatkan oleh laju kendaraan yang melebihi batas wajar (International Transport Forum, 2018).

Sikap seseorang dalam berkendara dipengaruhi oleh lingkungan, misalnya dari lingkungan pertemanan dan pola asuh orang tua. Doron \& Sharbani (2013) menyebutkan bahwa setiap pola asuh memiliki ciri tersendiri dan dapat menimbulkan kepribadian yang berbedabeda pada setiap individu.

Baumrind mengklasifikasikan pola asuh ke dalam 3 kelompok, yakni autoritatif, autoritarian, dan permisif. Setiap jenis pola asuh memiliki karakteristik pengasuhan yang berbeda. Untuk mengidentifikasi kecenderungan pola asuh yang diterapkan, para ahli telah menemukan sejumlah instrumen, salah satunya yakni Parenthal
Authority Questionnaire (PAQ) (Zulfiqar, 2017).

PAQ merupakan salah satu self reported instrument yang dapat digunakan untuk mengidentifikasi pola pengasuhan yang diterapkan orang tua responden. Responden bisa melengkapi pertanyaan dalam kuesioner tersebut tanpa harus didampingi oleh ahli. PAQ terdiri dari 30 item pertanyaan dengan 5 poin skala likert. Masing-masing tipe pola asuh diwakili oleh 10 item pertanyaan yang disusun secara acak. Penentuan pola asuh yang paling dominan dilakukan dengan penjumlahan dari setiap kelompok item (Buri, 1991).

Kategori kedua menurut Haddon Matrix yaitu agent. Faktor risiko kecelakaan lalu lintas yang terkait dengan agent yaitu jenis kecelakaan, misalnya kecelakaan yang terjadi antar sesama sepeda motor, sepeda motor dengan mobil, atau pejalan kaki dengan sepeda motor. Kategori yang ketiga yakni environment atau lingkungan. Lingkungan yang merupakan faktor risiko dari kecelakaan misalnya keberadaan rambu dan marka jalan, kondisi jalanan, dan cuaca (Masoumi et al., 2016).

Penelitian Saputra (2017) menunjukkan, kecelakaan lebih cenderung terjadi pada pukul 12.00-18.00, dimana merupakan jam sibuk. Faktor lingkungan lainnya yakni kondisi jalan. Konstruksi jalan yang kurang sempurna dan kurangnya rambu atau marka jalan adalah salah satu kondisi yang mendukung terjadinya kecelakaan.

Adanya interaksi antara ketiga kategori faktor risiko tersebut bisa berdampak terhadap tingkat keparahan cedera maupun kerugian yang ditimbulkan. Penelitian ini dilakukan guna mengidentifikasi pengaruh pola asuh dengan jenis kelamin terhadap kejadian kecelakaan sepeda motor yang dialami oleh pelajar SMA.

\section{METODE PENELITIAN}

Penelitian ini merupakan penelitian cross sectional analitik. Responden dalam penelitian ini adalah pelajar SMA kelas XI yang merupakan pengendara aktif dalam kurun waktu enam bulan terakhir. Sebelum proses pengumpulan data dilakukan, peneliti telah mengikuti kaji etik yang 
diselenggarakan oleh Komite Etik Penelitian Kesehatan Fakultas Kesehatan Masyarakat Universitas Airlangga (FKM UNAIR) dengan nomor sertifikat 200-KEPK.

Responden diminta mengisi instrumen berupa kuesioner yang berisi data diri (usia, gender, riwayat kecelakaan lalu lintas dalam 6 bulan terakhir) dan Parenthal Authority Questionnaire (PAQ) sebagai instrumen untuk mengidentifikasi pola pengasuhan orang tua terhadap anak. PAQ terdiri dari 30 item pertanyaan. Setiap 10 item pertanyaan merepresentasikan 1 jenis pola asuh. Pengisian dilakukan sendiri oleh responden dengan memilih 1 dari 5 skala likert (sangat tidak setuju-sangat setuju). Jenis pola asuh yang diidentifikasi yakni autoritatif, autoritarian, dan permisif. Orangtua dengan pola asuh autoritarian cenderung memaksakan banyak peraturan dan kehendak, serta mengharapkan kepatuhan, namun tidak memberikan alasan mengapa anak harus mematuhi peraturan yang dibuat. Orangtua dengan pola asuh autoritatif memberikan peraturan dan alasan yang jelas terhadap peraturan tersebut. Orangtua juga memiliki kekuasaan, namun anak tetap memiliki hak untuk menyampaikan pendapat. Sedangkan orangtua permisif memiliki sifat penyabar, memberikan pengendalian terhadap anak agar mereka berperilaku matang, mendorong mereka untuk menunjukkan apa yang mereka rasakan, dan cenderung jarang mengontrol perilaku mereka (Buri, 1991).

Penentuan pola asuh dominan dilakukan dengan cara menjumlahkan item pertanyaan sesuai dengan setiap tipe. Skor setiap tipe pola asuh yakni antara $10-50$. Tipe pola asuh paling dominan dapat diketahui dari jumlah terbanyak dari setiap jenis pola asuh (Buri, 1991). Tahap selanjutnya adalah analisis data yang telah terkumpul menggunakan regresi logistik dan tabulasi silang dengan aplikasi komputer.

\section{HASIL PENELITIAN}

\section{Karakteristik Responden}

Berdasarkan Tabel 1, sebanyak 222 responden usia 17-19 terlibat dalam penelitian ini dengan 50,5\% diantaranya berjenis kelamin lakilaki. Hasil analisis kuesioner PAQ didapatkan
Tabel 1. Karakteristik Responden

\begin{tabular}{lcc}
\hline \multicolumn{1}{c}{ Karakteristik } & $\mathbf{f}(\mathbf{n}=\mathbf{2 2 2})$ & $\mathbf{\%}$ \\
\hline Usia & & \\
\hline 17 Tahun & 199 & 89,6 \\
18 Tahun & 22 & 9,9 \\
19 Tahun & 1 & 0,5 \\
\hline Jenis Kelamin & & \\
\hline Laki-laki & 112 & 50,5 \\
Perempuan & 110 & 49,5 \\
\hline Status Kecelakaan & & \\
\hline Tidak Pernah & 193 & 86,9 \\
Pernah & 29 & 13,1 \\
\hline Pola Asuh & & \\
\hline Autoritatif & 173 & 77,9 \\
Autoritarian & 33 & 7,9 \\
Permisif & 16 & \\
\hline
\end{tabular}

bahwa mayoritas responden dibesarkan dengan pola asuh autoritatif $(77,9 \%)$. Seluruh responden merupakan pengendara sepeda motor aktif. Mayoritas responden tidak pernah mengalami kecelakaan $(86,9 \%)$ dalam kurun waktu enam bulan terakhir.

\section{Jenis Kelamin dan Kecelakaan Lalu Lintas}

Hasil tabulasi silang antara jenis kelamin dan pengalaman kecelakaan lalu lintas responden ditampilkan pada Tabel 2. Tabel 2 menunjukkan bahwa kecelakaan lalu lintas didominasi responden laki-laki dibandingkan perempuan, dengan jumlah responden sebanyak 19 orang $(17 \%)$.

\section{Pola Asuh Orang Tua dan Kecelakaan Lalu Lintas}

Hasil cross tabulation antara variabel pola asuh orang tua dengan pengalaman kecelakaan lalu lintas responden ditampilkan dalam Tabel 3. Tabel 3 menunjukkan bahwa proporsi kecelakaan terbesar terjadi pada responden laki-laki dengan pola asuh autoritarian.

\section{Pengaruh Pola Asuh dengan Kecelakaan Lalu Lintas}

Pengaruh pola asuh dengan kecelakaan lalu lintas dianalisis dengan menggunakan regresi logistik dengan cut value 0,50 dan overall 
Tabel 2. Hubungan antara Jenis Kelamin dengan Pengalaman Kecelakaan

\begin{tabular}{cccccc}
\hline \multirow{2}{*}{$\begin{array}{c}\text { Jenis } \\
\text { Kelamin }\end{array}$} & \multicolumn{3}{c}{ Pengalaman Kecelakaan Lalu Lintas } & \multirow{2}{*}{ Total } \\
\cline { 2 - 6 } & \multicolumn{3}{c}{ Pernah } & Tidak & \\
\cline { 2 - 6 } & f & 17 & 93 & 83 & $112(100 \%)$ \\
Laki-laki & 19 & 17 & 100 & 90,9 & $110(100 \%)$ \\
Perempuan & 10 & 9,1 & & & \\
\hline
\end{tabular}

Tabel 3. Tabulasi Silang antara Jenis Kelamin, Pola Asuh Orang Tua, dan Pengalaman Kecelakaan

\begin{tabular}{|c|c|c|c|c|c|c|}
\hline \multirow{3}{*}{ Jenis Kelamin } & \multirow{3}{*}{ Pola Asuh } & \multicolumn{4}{|c|}{ Pengalaman Kecelakaan Lalu Lintas } & \multirow{3}{*}{ Total } \\
\hline & & \multicolumn{2}{|c|}{ Pernah } & \multicolumn{2}{|c|}{ Tidak Pernah } & \\
\hline & & f & $\%$ & f & $\%$ & \\
\hline \multirow{3}{*}{ Laki-laki } & Autoritatif & 14 & 17,1 & 68 & 82,9 & $82(100 \%)$ \\
\hline & Autoritarian & 4 & 22,2 & 14 & 77,8 & $18(100 \%)$ \\
\hline & Permisif & 1 & 17 & 11 & 91,7 & $12(100 \%)$ \\
\hline \multirow{3}{*}{ Perempuan } & Autoritatif & 7 & 7,7 & 84 & 92,3 & $91(100 \%)$ \\
\hline & Autoritarian & 2 & 13,3 & 13 & 86,7 & $15(100 \%)$ \\
\hline & Permisif & 1 & 25 & 3 & 75 & $4(100 \%)$ \\
\hline
\end{tabular}

Tabel 4. Regresi Logistik Pola Asuh dengan Kecelakaan Lalu Lintas

\begin{tabular}{lcccc}
\hline \multicolumn{1}{c}{ Variabel } & B & $\boldsymbol{p}$ & $\mathbf{E x p ( B )}$ & Keterangan \\
\hline Pola Asuh & & & & \\
Autoritarian & $-0,033$ & 0,966 & 0,967 & Tidak Bermakna \\
Permisif & 0,442 & 0,616 & 1,556 & Tidak Bermakna \\
\hline
\end{tabular}

percentage $86,9 \%(>75 \%)$ sehingga telah memenuhi syarat klasifikasi kasus. Pola asuh yang digunakan sebagai reference group yakni pola asuh autoritatif yang disajikan dalam Tabel 4.

\section{PEMBAHASAN}

\section{Jenis Kelamin}

Hasil penelitian yang menunjukkan bahwa proporsi laki-laki yang pernah mengalami kecelakaan lalu lintas lebih banyak dibandingkan perempuan sejalan dengan penelitian yang dilakukan oleh Desiartama \& Aryana (2017) tentang karakteristik pasien kecelakaan lalu lintas yang mengalami fraktur femur di RS Sanglah Denpasar. Sebanyak 113 pasien kecelakaan terlibat sebagai responden dalam penelitian. Sebesar 69,1\% diantaranya berjenis kelamin laki-laki. Nadzira, Yuniarti dan Fitriyana (2017) juga menemukan hal serupa. Penelitiannya menunjukkan hasil bahwa mayoritas korban kecelakaan lalu lintas laki-laki, dengan proporsi $56,1 \%$ dari total 41 responden.

Penelitian lain yang dilakukan di Iran oleh Masoumi et al., (2016) menunjukkan hasil serupa. Responden dalam penelitian tersebut merupakan pasien kecelakaan lalu lintas yang menerima perawatan di rumah sakit. Dari 700 pasien yang menerima perawatan, $92,4 \%$ diantaranya adalah laki-laki. Hasil serupa juga ditunjukkan pada penelitian di Kota Surabaya, yang menunjukkan bahwa pengalaman kecelakaan lebih banyak dialami oleh siswa laki-laki (19\%) dibandingkan perempuan (10\%) (Bayumi, 2018).

Hidayati \& Hendrati (2016) menunjukkan hasil penelitian yang bertolak belakang. Hidayati dan Hendrati mengungkapkan bahwa kecelakaan lalu lintas lebih cenderung dialami perempuan $(48,89 \%)$. 
Darmawan (2015) dalam penelitiannya menyebutkan, ada perbedaan tingkat agresifitas dalam berkendara antara laki-laki dan perempuan. Penelitian tersebut menyebutkan bahwa lakilaki lebih cenderung berkendara secara agresif dibandingkan perempuan. Penelitian ini didukung oleh Plankermann (2013) yang menyebutkan bahwa pengendara laki-laki lebih cenderung memiliki kebiasaan berkendara yang berisiko.

Penelitian yang dilakukan oleh Handayani, Laksono dan Novitiana (2017) tentang perilaku agresif terhadap potensi kecelakaan menunjukkan hasil bahwa 68\% kecelakaan lalu lintas yang dialami responden diakibatkan oleh sifat berkendara yang agresif. Soffania (2018) mengungkapkan hasil penelitian serupa, bahwa ada hubungan antara sikap agresif saat mengendarai motor dengan kejadian kecelakaan.

Sejumlah penelitian terkini mengemukakan bahwa laki-laki dan perempuan mempunyai persepsi yang sama terhadap kondisi berisiko atau berbahaya. Namun yang membedakan diantara keduanya yakni perempuan lebih perhatian terhadap efek yang ditimbulkan dari kondisi berisiko atau berbahaya tersebut (Cordellieri et al., 2016). Berdasarkan sejumlah penelitian dan penjelasan tersebut dapat diketahui bahwa salah satu faktor risiko dari besarnya proporsi laki-laki yang mengalami kecelakaan lalu lintas yakni sikap berkendara yang agresif.

\section{Pola Asuh}

Analisis kuesioner PAQ menunjukkan bahwa mayoritas responden dibesarkan secara autoritatif yang lebih dominan. Orang tua yang menggunakan tipe pola asuh autoritatif menerapkan tingkat tanggung jawab dan pengontrolan yang tinggi pada anak. Contoh tindakan dari orang tua autoritatif yakni anak diberikan kebebasan dalam menyampaikan pendapat (demokratis), serta memberikan perhatian dan dukungan pada kebutuhan dan kemampuan anak, mendidik anak untuk tidak selalu bergantung pada orang lain.

Hasil analisis pengaruh pola asuh terhadap kecelakaan lalu lintas menunjukkan bahwa diantara ketiga jenis pola asuh, yang memiliki risiko paling tinggi adalah permisif. Penelitian
Naimah (2015) tentang survei pola asuh di Kecamatan Kunir, Lumajang, menemukan hasil serupa bahwa sebanyak 58\% (87 responden) remaja dibesarkan dengan pola asuh autoritatif yang lebih dominan dibanding dua tipe pola asuh yang lain. Rahmayanti \& Pujiastuti (2012) juga menemukan hasil serupa dalam penelitiannya, dimana sebanyak 26 dari 37 responden dibesarkan dengan pola asuh autoritatif.

Hasil yang berbeda ditunjukkan oleh Aini. Penelitian tersebut menunjukkan bahwa dari total 40 remaja yang menjadi responden, 26 orang (65\%) mengalami pola asuh autoritarian. Remaja yang mengalami pola asuh demokratis atau autoritatif sebanyak $30 \%$, dan sisanya permisif (Aini, 2014).

Orang tua dengan pola pengasuhan autoritatif lebih dominan, pada waktu tertentu juga dapat menerapkan pola asuh autoritarian dan permisif. Orang tua dapat menentukan pola asuh yang sesuai dengan kondisi perkembangan emosional putra-putri mereka (Naimah, 2015).

Setiap pola asuh membawa dampak yang berbeda terhadap timbulnya karakter remaja. Karakter remaja yang diasuh secara autoritatif akan memiliki perbedaan dengan remaja yang dibesarkan secara autoritarian atau permisif (Buri, 1989).

Riset yang dilakukan oleh Hoskins (2014) menyebutkan bahwa karakteristik seseorang pada saat dewasa terbentuk dari banyak faktor, misalnya adalah pola asuh orang tua. Faktor lain yang juga mempengaruhi, misalnya kondisi lingkungan atau daerah tempat tinggal dan nilai budaya yang ada di masyarakat. Remaja yang dibesarkan dengan pola asuh autoritatif pada suatu etnis dapat memiliki karakteristik yang berbeda dengan etnis yang lain.

Karakter yang timbul dari pola pengasuhan orang tua sejak kecil dapat mempengaruhi tingkah laku sehari-hari, misalnya ketika berkendara. Muir et al., (2010) menyebutkan bahwa orang tua mempunyai peran yang cukup besar dalam perilaku berkendara yang baik. Dalam laporan penelitian tersebut, tipe pola asuh dengan tingkat keterlibatan yang tinggi berhubungan positif dengan sikap berkendara yang aman pada anak. 
Hoskins (2014) menyebutkan dalam penelitiannya, bahwa karakteristik positif pada diri remaja paling memungkinkan terjadi pada remaja yang diasuh secara autoritatif. Hasil penelitian serupa ditunjukkan pula oleh Miller (2010) bahwa remaja yang dibesarkan secara autoritarian cenderung memiliki kepercayaan diri yang rendah, kurang mampu bersosialisasi dengan sekitar, mudah marah, cemas, dan depresi.

Aini (2014) menemukan keterkaitan pola asuh dengan kepribadian yang dimiliki oleh remaja. Aini menyebutkan, pola asuh otoriter atau disebut juga sebagai autoritarian cenderung dapat menimbulkan sikap nakal pada remaja. Fellasari \& Lestari (2016) menyebutkan bahwa setiap pola asuh berkontribusi dalam kematangan emosi remaja. Pola asuh autoritatif dan permisif memberikan dampak positif terhadap kematangan emosi remaja, namun pola asuh autoritarian memberikan dampak sebaliknya.

Penelitian tersebut didukung oleh Faridah \& Atakari (2018) yang menyebutkan, terdapat hubungan antara pola pengasuhan orang tua terhadap penggunaan Narkotika, Alkohol, Psikotropika dan Zat Adiktif (NAPZA). Responden yang merupakan pengguna NAPZA mayoritas dibesarkan dengan pola asuh autoritarian yang lebih dominan.

Hasil crosstab pola asuh dan pengalaman kecelakaan sepeda motor menunjukkan hasil bahwa proporsi remaja yang tidak mengalami kecelakaan sepeda motor dalam enam bulan terakhir dan dibesarkan secara autoritatif lebih besar pola asuh permisif atau autoritarian. Hasil ini didukung oleh Ginsburg et al., (2009) yang mengemukakan bahwa remaja yang diasuh secara autoritarian dan permisif lebih cenderung mengalami kecelakaan lalu lintas dibandingkan pola asuh autoritatif. Ginsburg menambahkan, bahwa remaja yang diasuh secara autoritatif lebih berisiko menjadi pelaku kecelakaan lalu lintas dibandingkan dengan remaja yang diasuh secara authoritarian.

Kecelakaan lalu lintas yang terdata mayoritas terjadi karena ketidakpatuhan dalam berkendara, misalnya lalai, agresif saat berkendara dengan kecepatan tinggi, maupun melawan rambu lalulintas (KORLANTAS POLRI, 2014). Remaja yang diasuh secara pola asuh autoritatif lebih cenderung tidak melakukan tindakan lalai atau yang berpotensi mengurangi konsentrasi berkendara, seperti merokok dan menggunakan telepon genggam (Ginsburg et al., 2009).

Uraian beberapa penelitian tersebut dapat ditarik kesimpulan bahwa pola asuh bukan merupakan faktor risiko utama penyebab terjadinya kecelakaan sepeda motor pada remaja. Hal ini disebabkan oleh adanya berbagai faktor lain yang juga dapat menyebabkan kecelakaan lalu lintas. Adanya interaksi dari berbagai faktor risiko tersebut kemudian dapat memungkinkan terjadinya kecelakaan.

\section{SIMPULAN DAN SARAN}

\section{Simpulan}

Kecelakaan lalu lintas lebih banyak dialami oleh responden laki-laki daripada perempuan. Kecelakaan lalu lintas tidak dipengaruhi oleh pola pengasuhan yang dilakukan orang tua, namun pola pengasuhan tersebut berperan dalam pembentukan karakteristik individu, salah satunya dalam hal pengambilan keputusan dan sikap berkendara.

\section{Saran}

Perlu dilakukan penelitian yang lebih mendalam guna mengidentifikasi pengaruh pola asuh orangtua terhadap cara pengambilan keputusan saat berkendara. Waktu kejadian kecelakaan, cuaca, kondisi jalan dan kendaraan, penggunaan handphone, merokok, maupun kondisi atau perilaku lain yang diduga memiliki kontribusi dalam terjadinya kecelakaan lalu lintas dapat diidentifikasi pada penelitian selanjutnya.

\section{DAFTAR PUSTAKA}

Aini, L.N., 2014. Hubungan Pola Asuh Orang Tua dengan Kenakalan Remaja di RW V Kelurahan Sidokare Kecamatan Sidoarjo. Jurnal Keperawatan dan Kebidanan, 6(1), pp.57-63.

Bayumi, F.Q.A., 2018. Analisis Hubungan Pola Asuh Orang Tua dengan Kejadian Kecelakaan Lalu Lintas pada Remaja Kelas 
XI SMA/Sederajat Tahun Ajaran 2017 di Kota Surabaya. Skripsi. Universitas Airlangga.

BPS Kota Surabaya, 2017. Kota Surabaya Dalam Angka 2017. Surabaya: Badan Pusat Statistik Kota Surabaya.

BPS Provinsi Jawa Timur, 2015. Jawa Timur Dalam Angka 2015. Surabaya: Badan Pusat Statistik Provinsi Jawa Timur.

Buri, J.R., 1989. An Instrument for the Measurement of Parental Authority Prototypes. In: the Annual Meeting of the Midwestern Psychological Association. Chicago.

Buri, J.R., 1991. Parental Authority Questionnaire. Journal of Personality Assessment, 57(1), pp.110-119.

Cordellieri, P., Baralla, F., Ferlazzo, F., Sgalla, R., Piccardi, L., Giannini, A.M., 2016. Gender Effects in Young Road Users on Road Safety Attitudes, Behaviors and Risk Perception. Frontiers in Psychology, 7, pp.1-11.

Darmawan, A., 2015. Hubungan antara Persepsi Kesesakan (Crowding) di Jalan Raya dengan Aggressive Driving Pengemudi Sepeda Motor Remaja di Yogyakarta yang dimoderatori oleh Jenis Kelamin. Universitas Gadjah Mada. Skripsi. Universitas Gadjah Mada.

Desiartama, A., Aryana, I.G.N.W., 2017. Gambaran Karakteristik Pasien Fraktur Femur Akibat Kecelakaan Lalu Lintas pada Orang Dewasa di Rumah Sakit Umum Pusat Sanglah Denpasar Tahun 2013. E-Jurnal Medika, 6(5), pp.1-4.

Doron, H., Sharbani, A., 2013. Parental Authority Styles of Parents with Attention Deficit Disorders (ADD). Open Journal of Social Sciences, 1(6), pp.43-49.

Faridah, Atakari, E.R., 2018. Hubungan Pola Asuh Orang Tua dengan Penggunaan Narkotika, Psikotropika, dan Zat Adiktif Lainnya (NAPZA) pada Remaja. Jurnal Kebidanan, 8(2), pp.138-142.

Fellasari, F., Lestari, Y.I., 2016. Hubungan antara Pola Asuh Orangtua dengan Kematangan Emosi Remaja. Jurnal Psikologi, 12(2), pp.84-90.

Ginsburg, K.R., Durbin, D.R., Garcia-Espana, J.F., Kalicka, E.A., Winston, F.K., 2009. Associations Between Parenting Styles and
Teen Driving, Safety-Related Behaviors and Attitudes. Pediatrics, 124(4), pp.1040-1051. Handayani, D., Laksono, D.E., Novitiana, L., 2017. Pengaruh Perilaku Agresif Terhadap Potensi Kecelakaan Pengendara Sepeda Motor Remaja Dengan Studi Kasus Pelajar SMA Kota Surakarta. Jurnal Riset Rekayasa Sipil, 1(1), pp.64-70.

Hidayati, A., Hendrati, L.Y., 2016. Analisis Risiko Kecelakaan Lalu Lintas Berdasar Pengetahuan, Penggunaan Jalur, dan Kecepatan Berkendara. Jurnal Berkala Epidemiologi, 4(2), pp.275287.

Hoskins, D.H., 2014. Consequences of Parenting on Adolescent Outcomes. Societies, 4(3), pp.506-531.

Indriastuti, A.K., Fauziah, Y., Priyanto, E., 2011. Karakteristik Kecelakaan dan Audit Keselamatan Jalan pada Ruas Ahmad Yani Surabaya. Jurnal Rekayasa Sipil, 5(1), pp.40-50.

International Transport Forum, 2018. Road Safety Annual Report 2018. France: International Traffic Safety Data and Analysis Group.

Kemenkes RI, 2012. Buletin Penyakit Tidak Menular. Jakarta: Kementerian Kesehatan Republik Indonesia.

Kemenkes RI, 2018. Profil Kesehatan Indonesia Tahun 2017. Jakarta: Kementerian Kesehatan Republik Indonesia.

KORLANTAS POLRI, 2014. POLANTAS dalam Angka Tahun 2013. Jakarta: Korps Lalu Lintas Kepolisian RI.

Masoumi, K., Forouzan, A., Barzegari, H., Darian, A.A., Rahim, F., Zohrevandi, B., Nabi, S., 2016. Effective Factors in Severity of Traffic Accident-Related Traumas; an Epidemiologic Study Based on the Haddon Matrix. Emergency, 4(2), pp.78-82.

Miller, M.J., 2010. Authoritarian Parenting: The Impact on Children. New Jersey: The Center for Christian Counseling \& Relationship Dev.

Muir, C., Devlin, A., Oxley, J., Kopinathan, C., Charlton, J., Koppel, S., 2010. Parents as Role Models in Road Safety. Australia: Monash University Accident Research Ctr.

Nadzira, A., Yuniarti, Fitriyana, S., 2017. Hubungan Usia, Jenis Kelamin, Jenis 
Kendaraan Pada Kecelakaan Lalu Lintas dengan Tipe Fraktur Ekstremitas Bawah di Rumah Sakit Al-Islam Tahun 2016. In: Prosiding Pendidikan Dokter. Bandung: Universitas Islam Bandung, pp.797-804.

Naimah, 2015. Survey Pola Asuh Orang Tua di Kecamatan Kunir Lumajang. Jurnal Kesehatan dan Budaya, 8(2), pp.40-47.

Plankermann, K., 2013. Human Factors as Causes for Road Traffic Accidents in the Sultanate of Oman under Consideration of Road Construction Designs. Dissertation. University of Regensburg.

Rahmayanti, S.D., Pujiastuti, S., 2012. Hubungan Pola Asuh dengan Perkembangan Anak Usia Prasekolah di TK Kartika X-9 Cimahi 2012. Artikel Ilmiah. STIKES Jenderal Achmad Yani Cimahi.
Saputra, A.D., 2017. Studi Tingkat Kecelakaan Lalu Lintas Jalan di Indonesia Berdasarkan Data KNKT (Komite Nasional Keselamatan Transportasi) dari Tahun 2007-2016. Warta Penelitian Perhubungan, 29(2), pp.179-190.

Soffania, M.I., 2018. Hubungan Agressive Driving Behavior Pengemudi Sepeda Motor dengan Kecelakaan Lalu Lintas (Studi pada Siswa SMA di Kabupaten Sidoarjo). The Indonesian Journal of Public Health, 13(2), pp.220-231.

WHO, 2018. Global Status Report on Road Safety 2018. Geneva: World Health Organization.

Zulfiqar, N., 2017. Confirmatory Factor Analysis of Parental Authority Questionnaire: SES Differences among Pakistani Adolescents. Educational Psychology Papers and Publications, (223), pp.1-26. 